\title{
PERBANDINGAN PREVALENSI CACING GASTROINTESTINAL PADA SAPI BALI DAN LOKAL DI KABUPATEN BANGGAI
}

\author{
${ }^{1}$ Wahyudin Abd. Karim \\ Fakultas Keguruan dan Ilmu Pendidikan \\ Universitas Muhammdiyah Luwuk \\ email:wahyudinabdulkarim87@gmail.com \\ ${ }^{2}$ Abd. Muin Kenta \\ Fakultas Keguruan dan Ilmu Pendidikan \\ Universitas Muhammdiyah Luwuk \\ email: muin@unismuhluwuk.ac.id
}

\begin{abstract}
The studies of gastrointestinal worm in cow have not been widely explored in Distric Luwuk Banggai. This study was aimed to Comparison of Prevalence of Gastrointestinal Worms in Bali and Local Cows in Banggai District. The fresh faecal samples were collected from 70 cows and observed by a modified McMaster technique. The faecal of cows were collected in south Luwuk, east Luwuk, North Luwuk, Manucipility Masama, Lamala, and Bualemo. The result of identification on gastrointestinal worm show that there were six genera of helminth i.e Moniezia, Haemonchus, Bunostomum, Oesophagostomum, Trichostrongylus, dan Capillaria. The prevalence in female was higher than male. The prevalence in kinds of cow was higher ongole cow than cow Bali.
\end{abstract}

Keywords: Cow, Prevelence, gastrointestinal worm, Distric Banggai 


\section{A. PENDAHULUAN}

Kabupaten Luwuk Banggai merupakan salah satu kabupaten yang terletak di daerah dataran rendah terbagi dalam 23 kecamatan. Ketinggian antara 1 sampai $61 \mathrm{mdpl}$ dengan suhu minimal $15.4{ }^{\circ} \mathrm{C}$, maksimal $34.7^{\circ} \mathrm{C}$, dan rata-rata $26.2{ }^{\circ} \mathrm{C}-30 \quad{ }^{\circ} \mathrm{C}$, kelembaban sekitar minimal $44 \%$, maksimal $91 \%$, dan ratarata $65-79 \%$, curah hujan $98.3 \mathrm{~mm}$ per tahun, jumlah hujan rata-rata 15 hari perbulan (BPS 2015), letaknya berkisar antara $0^{\circ} 30^{\prime}$ dan $2^{0} 20^{\prime} \mathrm{LU}$ dan $122^{\circ} 23^{\prime}$ dan $124^{\circ} 20^{\prime} B T$, sedangkan jumlah ternak sapi ada sekitar 61.318 ekor (BPS, 2013).

Sapi Bali telah tersebar hampir di seluruh provinsi di Indonesia dan berkembang cukup pesat di daerah karena memiliki beberapa keunggulan (Guntoro, 2002). Kendala yang banyak dihadapkan oleh peternak dalam pemeliharaan Sapi Bali adalah infeksi penyakit. ciri-ciri fisik sapi Bali adalah berukuran sedang, berdada dalam dengan kaki yang bagus. Warna bulu merah bata dan coklat tua yang dikenal juga walaupun tidak umum. Bibir, kaki dan ekor berwarna hitam dan kaki putih dari lutut kebawah, dan ditemukan warna putih di bawah paha dan bagian oval putih yang amat jelas pada bagian pantat. Pada punggung ditemukan garis hitam disepanjang garis punggung yang disebut garis belut (Wiliamson dan Payne, 1993).

Pada umumnya, peternak di Daerah Kabupaten Luwuk Banggai tidak memiliki pengetahuan formal dalam pemeliharaan sapi, pengetahuan mereka hanya dari pengalaman beternak. Konstruksi kandang pada peternakan skala rakyat disetiap Kecamatan bervariasi sesuai dengan ketersediaan dana dan ketersediaan sumberdaya alam yang ada di sekitarnya. Tipe kandang yang banyak digunakan adalah kandang individual dan tidak mengalami kontak fisik dengan ternak lain dan bahkan ternak dibiarkan lepas di perkebunan.
Kehadiran fauna parasit terutama cacing pada hewan di peternakan merupakan salah satu permasalahan yang sering dihadapi peternak. Pola pemberian pakan, faktor-faktor lingkungan (suhu, kelembaban, dan curah hujan) serta sanitasi yang kurang baik dapat mempengaruhi berkembangnya parasit khususnya cacing gastrointestinal pada hewan ternak (Dwinata, 2004). Jenis-jenis cacing gastrointestinal yang menginfeksi sapi Bali adalah Bunostomum phlebotomum, Strongyloides papillosus, Trichostrongylus axei, Trichuris ovis dan tipe Strongyle (Alamsyah et al. 2015; Sajuri et al. 2017). Jenis-jenis cacing gastrointestinal yang menginfeksi sapi secara umum adalah Fasciolosis, nematodiasis, Strongyle, Coccidiosis, dan Paramphistomum sp. dan Trichuris sp. (Nurtjahyani et al. 2015; Dewi et al. 2016; Nugraheni, et al. 2018).

Perbedaan infeksi kecacingan pada jenis kelamin pada sapi lebih besar pada betina dibandingkan jantan (Nath, et al. 2016). Akan tetapi menurut Karim et al. (2016), bahwa Prevalensi cacing gastrointestinal pada jenis kelamin, lebih besar ditemukan di jantan dibandingkan betina, sedangkan untuk infestasi lebih besar ditemukan pada betina.

\section{B. METODE PENELITIAN Waktu dan Tempat}

Penelitian ini dilaksanakan pada bulan Febuari hingga Juli 2018. Pengambilan sampel feses sapi dilakukan di Kabupaten Banggai sebanyak 60 individu (30 sapi Bali dan 30 sapi Ongol). Pemeriksaan sampel feses dilakukan di Laboratorium Biologi Universitas Muhammadiyah Luwuk.

\section{Pengambilan Sampel Feses Sapi}

Sapi yang diamati adalah sapi yang dikandangkan dan digembalakan. Sampel feses yang diambil adalah sampel yang sudah ada di tanah dengan syarat feses masih dalam kondisi segar, selanjutnya disimpan di cool box. 


\section{Metode pengapungan (Floatation solution) pemeriksaan telur}

Teknik pemeriksaan sampel feses dilakukan dengan metode modifikasi pengapungan sederhana oleh Southwell et al. (2008). Feses sebanyak dua gram dimasukan ke dalam $60 \mathrm{ml}$ larutan $\mathrm{NaCl}$ jenuh, kemudian diaduk sampai homogen. Telur dalam feses akan mengapung dalam larutan garam karena berat jenis telur lebih ringan dibandingkan dengan larutan pengapung (floatation solution). Telur yang mengapung dilapisan paling atas diambil dengan pipet dan diteteskan ke dalam slide penghitung telur cacing (Mc Master).

\section{Identifikasi Cacing gastrointestinal} Identifikasi telur parasit gastrointestinal berdasarkan karakter, ukuran, dan jumlah sel (Foreyt 2001; Zajac dan Conboy 2011).

\section{Analisis Data}

Prevalensi

manajemen pemeliharaan, perbedaan lokasi, jenis kelamin dan umur dianalisis menggunakan perhitungan prevalensi berdasarkan Rehman et al. (2011) yaitu:

Prevalensi $(\%)=$ $\frac{\text { Jumlah sampel terinfeksi parasit }}{\text { Jumlah total sampel yang diperiksa }(N)} \times 100$

\section{HASIL DAN PEMBAHASAN}

Hasil penelitian terhadap 60 sampel feses yang diperiksa, didapatkan $(85 \%)$ positif terinfeksi cacing gastrointestinal dan $15 \%$ tidak terinfeksi. Setelah di identifikasi jenis cacing gastrointestinal yang menginfeksi sapi bali dan ongole adalah yaitu Moniezia, Haemonchus, Bunostomum, Oesophagostomum, Trichostrongylus, dan Capillaria.

Tabel 1. Morfologi Dan Morfometri Jenis Telur Cacing

\begin{tabular}{lll}
\hline No Jenis Cacing & $\begin{array}{l}\text { Morfologi dan Morfometri Telur } \\
\text { Cacing }\end{array}$ \\
\hline 1 & $\begin{array}{l}\text { Telur Haemonchus memiliki bentuk } \\
\text { oval, selnya berwarna kekuningan, } \\
\text { mempunyai tiga lapisan di kulit luar } \\
\text { dengan bentuk telur sama panjang, } \\
\text { serta mempunyai sel embrionik yang } \\
\text { hampir menutupi seluruh rongga telur }\end{array}$ \\
& $\begin{array}{l}\text { Hasil ini menunjukan Capillaria } \\
\text { memiliki dua kutub di ujung telur. } \\
\text { Telur Capillaria bentuknya memanjang } \\
\text { seperti galah, sel telur berwarna } \\
\text { kekuningan. }\end{array}$ \\
& Bentuk telur tumpul membulat, sel telur \\
& berwarna coklat kehitaman, dengan sel \\
& embrionik tidak menutupi seluruh \\
& rongga telur.
\end{tabular}




\begin{tabular}{ll}
\hline & $\begin{array}{l}\text { Telur Trichostrongylus mempunyai } \\
\text { ujung telur meruncing dan tumpul, } \\
\text { bagian luar Trichostrongylus tersusun } \\
\text { atas tiga lapisan, dinding berwarna } \\
\text { kekuningan dan sel embrionik tidak } \\
\text { menutupi seluruh rongga telur. }\end{array}$ \\
& $\begin{array}{l}\text { Hasil pengamatan menunjukan telur } \\
\text { genus Moniezia memiliki rentang } \\
\text { diameter telur } 28.63-60.79 \mu m \text { dan } \\
\text { berbentuk segitiga. }\end{array}$ \\
& $\begin{array}{l}\text { Telur Oesophagostomum memiliki } \\
\text { ujung telur membulat, lapisan kulit } \\
\text { luarnya tipis, sel telur berwarna kuning } \\
\text { gelap dan mempunyai tiga lapisan di } \\
\text { kulit luar, serta sel embrioniknya tidak } \\
\text { menutupi seluruh rongga telur }\end{array}$ \\
\hline
\end{tabular}

\begin{tabular}{|c|c|c|c|c|c|}
\hline $\begin{array}{l}\text { Prevalensi } \\
\text { Gastrointestinal } \\
\text { Sapi }\end{array}$ & $\begin{array}{l}\text { Infeksi } \\
\text { Berdasarkan }\end{array}$ & $\begin{array}{r}\text { Cacing } \\
\text { Jenis }\end{array}$ & $\begin{array}{l}P \\
\text { gastrointe } \\
\text { lebih bes } \\
(93.3 \%)\end{array}$ & $\begin{array}{l}\text { valensi } \\
\text { inal ber } \\
\text { ditemuk } \\
\text { bandingk }\end{array}$ & $\begin{array}{l}\text { telur cacing } \\
\text { arkan jenis sapi } \\
\text { pada sapi Ongol } \\
\text { sapi Bali }(80 \%) \text {. }\end{array}$ \\
\hline Jenis sapi & $\begin{array}{l}\text { Jumlah } \\
\text { Sampel } \\
\end{array}$ & Positif & $\begin{array}{c}\text { Persentase } \\
(\%)\end{array}$ & Negatif & Persentase (\%) \\
\hline Bali & 30 & 24 & 80 & 6 & 20 \\
\hline Ongole & 30 & 28 & 93.3 & 2 & 6.7 \\
\hline
\end{tabular}

Prevalensi Infeksi Cacing

Gastrointestinal Berdasarkan Jenis

Kelamin Sapi

Prevalensi telur cacing

gastrointestinal berdasarkan jenis

\begin{tabular}{lccccc}
\hline Jenis Kelamin & $\begin{array}{c}\text { Jumlah } \\
\text { Sampel }\end{array}$ & Positif & $\begin{array}{c}\text { Persentase } \\
(\boldsymbol{\%})\end{array}$ & Negatif & Persentase (\%) \\
\hline Jantan & 30 & 26 & 86.7 & 4 & 13.3 \\
Betina & 30 & 27 & 90 & 2 & 10 \\
\hline
\end{tabular}

Prevalensi Cacing Gastrointestinal Yang Menginfeksi Sapi

Prevalensi telur cacing gastrointestinal yang menginfeksi sapi lebih besar ditemukan pada jenis cacing Haemonchus sebesar $50 \%$ dan terkecil pada Moniezia $7.1 \%$. kelamin lebih besar ditemukan pada betina dibandingkan jantan yaitu sebesar $90 \%$.
Tabel $6 \quad$ Prevalensi cacing gastrointestinal Yang Menginfeksi Sapi 


\begin{tabular}{llccc}
\hline No & Jenis Cacing & Jumlah Sampel & Positif & Prevalensi (\%) \\
\hline 1 & Haemonchus & 70 & 35 & 50 \\
2 & Bunostomum & 70 & 20 & 28.6 \\
3 & Moniezia & 70 & 5 & 7.1 \\
4 & Trichostrongylus & 70 & 7 & 10 \\
5 & Oesophagostomum & 70 & 13 & 18.6 \\
6 & Capillaria & 70 & 9 & 12.9 \\
\hline
\end{tabular}

\section{Prevalensi Cacing Gastrointestinal} Berdasarkan Faktor Jenis kelamin

Berdasarkan hasil pengamatan menunjukan bahwa prevalensi tertinggi pada jenis kelamin betina yaitu sebesar $90 \%$. Penelitian sebelumnya melaporkan bahwa infeksi Cacing Gastrointestinal lebih besar ditemukan pada jenis kelamin jantan (Paramitha, et. al 2017). Beberapa penelitian lain menemukan bahwa tidak ada hubungan antara jenis kelamin dengan tingkat infeksi cacing gastrointestinal. Terjadinya perbedaan tingkat prevalensi pada jenis kelamin lebih dipengaruhi oleh pola diet (Raza et al. 2013).

\section{Prevalensi Cacing Gastrointestinal Berdasarkan Faktor Umur \\ Umur merupakan salah satu} faktor penting yang memiliki dampak serius terhadap prevalensi cacing

\section{PENUTUP}

Jenis - jenis telur cacing gastrointestinal yang ditemukan dalam saluran pencernaan sapi di Kabupaten Banggai ada enam genus, yaitu Moniezia, Haemonchus, Bunostomum, Trichostrongylus, Oesophagostomum, Capillaria.

Prevalensi

cacing gastrointestinal pada jenis sapi, lebih besar ditemukan di sapi ongol dibandingkan bali, sedangkan prevalensi cacing gastrointestinal pada jenis kelamin, lebih besar ditemukan di betina dibandingkan jantan. gastrointestinal pada sapi (Patel et al. 2015). Semua umur berisiko terinfeksi cacing gastrointestinal. Kelompok umur sapi memiliki tingkat kekebalan terhadap cacing parasit yang berbeda, dikarenakan sistem kekebalan tubuh. Tingkat infeksi lebih tinggi pada ruminansia yang masih muda dibandingkan dengan ruminansia lebih dewasa. Hal ini disebabkan ruminansia masih muda memiliki perlawanan antibodi terhadap cacing gastrointestinal lebih rendah (Colditz et al. 1996; Khan et al. 2010). Infeksi cacing gastrointestinal pada sapi berumur muda dapat terjadi akibat beberapa cara diantaranya adalah akibat terinfeksi oleh sapi lain, sanitasi kandang yang kurang baik dan pemeliharaan dalam satu kandang dengan sapi berumur yang lebih tua (Nugraha 2015).

\section{E. DAFTAR PUSTAKA}

Alamsyah AN, Dwinata, IM, Oka, IBM. 2015. Prevalensi Nematoda Gastrointestinal pada Sapi Bali di Sentra Pembibitan Desa Sobangan, Mengwi, Badung. Indonesia Medicus Veterinus, 4(1) : 80-87.

Colditz IG, Watson DL, Gray GD, Eady SJ. 1996. Some relationship between age, Immune responsiveness and resistance to parasite in ruminant. Int $J$ Parasitol. 26 (8/9): 869-877.

Dewi DA, Wardhana AH, Sawitri DH, Ekawasti F, Akbari RA. 2016. 
Parasitic Diseases in Dairy Cattle in Cibungbulang District of West Java. Proc.Intsem.LPVT-p.170-177

Foreyt WJ. 2001. Veterinary Parasitology Reference Manual. Amerika Serikat (US). Blackwell Publishing.

Guntoro. S. 2002. Membudidayakan Sapi Bali. Kanisius, Yogjakarta.

Khan MN, Sajid MS, Kasib MK, Iqbal Z, Hussain A. 2010. Gastrointestinal helminthiasis: prevalence and associated determinants in domestic ruminants of district Toba Tek Singh, Punjab, Pakistan. Parasitol Res. 107(4): 787-794.

Nath, TC, Islam, KM, Ilyas, N, Chowdhury, SK, Bhuiyan, JU. 2016. Assessment of the Prevalence of Gastrointestinal Parasitic Infections of Cattle in Hilly Areas of Bangladesh. World Scient if ic News, 59: 7484

Nugraheni, YR, Priyowidodo, D, Prastowo, J, Rohayati, ES, Sahara, A, Awaludin A. 2018. Parasit Gastrointestinal Pada Sapi Di Daerah Aliran Sungai Progo Yogyakarta. Jurnal Imu Peternakan Terapan. 2(1):1-5.

Nurtjahyani, S and Agustin, DS. 2015. Comparison of parasite infection degree in cattle (Bos sp.) using faecal egg counting method in two East Java regions, Lamongan and Gresik. Asian Pac J Trop Dis, 5(8): 614-616.

Paramitha, RP, Ernawati, R, Koesdarto, S. 2017. The Prevalence of Gastrointestinal Tract Helminthiasis Through Stool Examination in Cattle at Benowo Landfill Surabaya. Journal of Parasite Science, 1 (1): 23-32.
Nugraha AB. 2015. Kajian Prevalensi dan Faktor Risiko Kriptosporidiosis pada Peternakan Sapi Perah di Kabupaten Bogor [Tesis]. Bogor (ID): Institut Pertanian Bogor.

Raza MA, Iqbal Z, Jabbar A, Yassen M. 2007. Point prevalence of gastrointestinal helminthiasis in ruminants in southern Punjab, pakistan. J Helmin. 81(3):323328.

Rehman TU, Khan MN, Sajid MS, Abbas RZ, Arshad M, Iqbal Z, Iqbal A. 2011. Epidemiology of Eimeria and associated risk factors in cattle of district Toba Tek Singh, Pakistan. Parasitol. Res. 108: 1171-1177

Sajuri, IAS Dwinata, IM, Oka, IBM. 2017. The Prevalence Of Helminth Infection In Cattle Gastrointestinal Nematodes Bali In Final Disposal (TPA) Suwung Denpasar. Indonesia Medicus Veterinus, 6(1): 78-85.

Southwell, Jason, Fisk C, Sallur N. 2008. Internal Parasite Control in Sheep Reference Manual. Deborah Maxwell, DPI, and Queensland F, editor. South Wales (GB). Sheep CRC.

Karim, WA, Farajallah, A, Suryobroto, B. Exploration and prevalence of gastrointestinal worm in buffalo from West Java, Central Java, East Java and Lombok, Indonesia. Aceh Journal of Animal Science 1(1): 1-15.

Williamson, G. dan W. J. A. Payne. 1993. Pengantar Peternakan di Daerah Tropis. Gadjah Mada University Press. Yogyakarta.

Zajac AM, Conboy GA. 2011. Veterinary Clinical parasitology. Amerika Serikat (US). Blackwell Publishing. 